\title{
Apoptosis-Inducing Factor Is a Key Factor in Neuronal Cell Death Propagated by BAX-Dependent and BAX-Independent Mechanisms
}

\author{
Eric C. C. Cheung, ${ }^{1}$ Lysanne Melanson-Drapeau, ${ }^{2}$ Sean P. Cregan, ${ }^{1}$ Jacqueline L. Vanderluit, ${ }^{1}$ Kerry L. Ferguson, ${ }^{1}$ \\ William C. McIntosh, ${ }^{1}$ David S. Park, ${ }^{1}$ Steffany A. L. Bennett, ${ }^{2}$ and Ruth S. Slack ${ }^{1}$ \\ ${ }^{1}$ Ottawa Health Research Institute, Neuroscience Center and Department of Cellular and Molecular Medicine, and ${ }^{2}$ Neural Regeneration Laboratory, \\ Department of Biochemistry, Microbiology, and Immunology, University of Ottawa, Ottawa, Ontario, Canada K1H 8M5
}

\begin{abstract}
Mitochondria release proteins that propagate both caspase-dependent and caspase-independent cell death pathways. AIF (apoptosisinducing factor) is an important caspase-independent death regulator in multiple neuronal injury pathways. Presently, there is considerable controversy as to whether AIF is neuroprotective or proapoptotic in neuronal injury, such as oxidative stress or excitotoxicity. To evaluate the role of AIF in BAX-dependent (DNA damage induced) and BAX-independent (excitotoxic) neuronal death, we used Harlequin $(\mathrm{Hq})$ mice, which are hypomorphic for AIF. Neurons carrying double mutations for $\mathrm{Hq} / \mathrm{Apaf1^{-/ }}{ }^{-}$(apoptosis proteases-activating factor) are impaired in both caspase-dependent and AIF-mediated mitochondrial cell death pathways. These mutant cells exhibit extended neuroprotection against DNA damage, as well as glutamate-induced excitotoxicity. Specifically, AIF is involved in NMDA- and kainic acid- but not AMPA-induced excitotoxicity. In vivo excitotoxic studies using kainic acid-induced seizure showed that $\mathrm{Hq}$ mice had significantly less hippocampal damage than wild-type littermates. Our results demonstrate an important role for AIF in both BAXdependent and BAX-independent mechanisms of neuronal injury.
\end{abstract}

Key words: AIF; excitotoxicity; neuron; caspase independent; kainic acid; apoptosis

\section{Introduction}

Mitochondria relay signals for both caspase-dependent and caspase-independent death pathways. The caspase-dependent pathway is initiated by release of cytochrome $c$, which associates with APAF1 (apoptosis proteases-activating factor) to activate caspases (Danial and Korsmeyer, 2004). One key mitochondrial protein in caspase-independent death pathway is the flavoprotein AIF (apoptosis-inducing factor) (for review, see Cregan et al., 2004). In healthy cells, mitochondrial AIF may protect against oxidative stress (Klein et al., 2002). Once cell death is initiated, however, AIF translocates to the nucleus to execute DNA fragmentation that culminates in cell death (Lorenzo et al., 1999; Cande et al., 2002a,b).

Previous studies suggested that AIF may be important in neu-

Received 0ct. 13, 2004; revised Dec. 17, 2004; accepted Dec. 17, 2004.

This work is supported by grants from the Canadian Institutes of Health Research (CIHR) (R.S.S., S.A.L.B.), the Heart and Stroke Foundation of (anada (HSFC) (R.S.S.), the Canadian Stroke Network (CSN) (R.S.S), and the Natural Sciences and Engineering Research Council of Canada (S.A.L.B.). The adenovirus core facility is supported by a grant from CSN (R.S.S. and D.S.P.). L.M.-D. is supported by a Canadian Graduate Scholarship. S.P.C. was supported by a CIHR postdoctoral fellowship. J.L.V. is supported by an HSFC fellowship. K.L.F. is supported by a CIHR studentship. D.S.P. is a Glaxo-Welcome Professor. S.A.L.B. is an Ontario Mental Health Foundation Intermediate Investigator and a CIHR new investigator. We thank Nicole Arbour and André Fortin for critical reading of this manuscript.

Correspondence should be addressed to Dr. Ruth S. Slack, Ottawa Health Research Institute, University of Ottawa, 451 Smyth Road, Ottawa, Ontario, Canada K1H 8M5. E-mail: rslack@uottawa.ca.

S. P. Cregan's present address: Robarts Research Institute, Cell Biology Group, P.0. Box 5015, 100 Perth Drive, London, Ontario, Canada N6A 5K8.

DOI:10.1523/JNEUROSCI.4261-04.2005

Copyright $\odot 2005$ Society for Neuroscience $\quad$ 0270-6474/05/251324-11\$15.00/0 ronal injury. AIF translocates to the nucleus after DNA damage, excitotoxicity, and in vivo ischemia (Susin et al., 1999b; Joza et al., 2001; Plesnila et al., 2004). Microinjection of AIF-neutralizing antibodies decreased BAX-mediated neuronal apoptosis when caspases are inhibited (Cregan et al., 2002). PARP1 [poly(ADPribose) polymerase-1] activation is required for AIF translocation in $N$-methyl- $N^{\prime}$-nitro- $N$-nitrosoguanidine-induced damage or NMDA-induced excitotoxicity because AIF fails to translocate in PARP1 ${ }^{-1-}$ neurons (Yu et al., 2002, 2003; Wang et al., 2003). PARP1 is overactivated in ischemia-reperfusion injury (Eliasson et al., 1997; Endres et al., 1997) and excitotoxicity (Zhang et al., 1994; Mandir et al., 2000). Consistently, the absence of PARP1 protects against excitotoxicity and cerebral ischemia (Moroni et al., 2001; Ying et al., 2001). These studies suggest that AIF is important in several mechanisms of acute neuronal injury.

A recent study with mice having $>80 \%$ reduced AIF expression, the "Harlequin" $(\mathrm{Hq})$ mice, suggests that AIF may also protect against oxidative stress (Klein et al., 2002). Presently, the role of AIF as a death executor or as an oxidative stress scavenger is controversial. There are limited studies examining the loss of AIF because Aif $^{-1-}$ mice die at embryonic day 3 (E3) (Joza et al., 2001). In $H q$ mice, instead of supernumerary cells attributable to failed apoptosis, surprisingly their cerebellum degenerates progressively and $\mathrm{Hq}$ neurons are more sensitive to oxidative stress. Although AIF has been suggested as a death inducer in excitotoxicity, $\mathrm{Hq}$ neurons are more sensitive to $2 \mathrm{~mm}$ glutamate treatment (Klein et al., 2002). This suggests that, in addition to inducing 
apoptosis, AIF may also protect against several types of neuronal injury.

To resolve the role of AIF in different mechanisms of neuronal injury, we asked whether AIF reduction in $\mathrm{Hq}$ mice could protect neurons against (1) BAX-mediated, DNA damage-induced apoptosis and (2) BAX-independent, NMDA receptor-mediated excitotoxicity (Miller et al., 1997; Dargusch et al., 2001). Using Hq/Apaf1 ${ }^{-1-}$ mice, we show that reduced AIF confers sustained protection in DNA damage-induced neuronal cell death when caspase activity was inhibited. Furthermore, $\mathrm{Hq}$ neurons exhibit a striking resistance specifically to NMDA- and kainic acidinduced excitotoxicity. Reduced levels of AIF also protect hippocampal neurons in vivo against cell death evoked by kainic acid-induced seizure. Our results demonstrate that AIF plays an important proapoptotic role in neuronal injury involving both BAX-dependent and BAX-independent cell death pathways.

\section{Materials and Methods}

Mice and primary neuronal cultures. Hq, Apaf1 $1^{-/-}$, and Bax ${ }^{-/-}$mice were maintained and genotyped as described previously (Fortin et al., 2001; Klein et al., 2002). Cortical neurons and cerebellar granule neurons (CGNs) were cultured from cortices of E15.5 mice and cerebellums of postnatal day 7 mice, respectively, as described previously (Fortin et al., 2001). Recombinant adenoviral vectors carrying human AIF or LacZ expression cassettes were prepared and used at 50 multiplicity of infection as described previously (Cregan et al., 2002).

Camptothecin treatment and cell viability assays. Neurons were treated with $10 \mu \mathrm{M}$ camptothecin with or without $10 \mu \mathrm{M}$ Boc-aspartyl (Ome)fluoromethylketone (BAF) (Enzyme System Products, Livermore, CA) after $2 \mathrm{~d}$ in vitro (DIV). Cell survival was measured by the following: live/dead staining (Molecular Probes, Eugene, OR), Hoechst staining, MTT assay (Cell Titer kit; Promega, Madison, WI), terminal deoxynucleotidyl transferase-mediated biotinylated UTP nick end labeling (TUNEL) assay, and propidium iodide (PI) staining, as described previously (Cregan et al., 2002). Caspase activity assay was performed as described previously (Cregan et al., 2002). Active caspase 3 immunohistochemistry (1:250; BD Biosciences, Franklin Lake, NJ) was performed according to the instructions of the manufacturer. AIF immunohistochemistry was performed as described previously (Cregan et al., 2002). For live/dead assay, survival was determined as the fraction of cells exhibiting positive staining for calcein-AM over the total cell number per field. For Hoechst staining, dead cells were indicated by the characteristic nuclear morphology of chromatin condensation. Representative samples were photographed using Zeiss (Oberkochen, Germany) Axiovert 100 with a Northern Eclipse Sony (Tokyo, Japan) Power HAD 3CCD color video camera.

Mitochondrial membrane potential. Loss of mitochondrial membrane potential was determined in unfixed cells using the membrane potentialdependent dye Mitotracker chloromethyl X-rosamine (CMX-Ros) and tetramethylrhodamine ethyl ester (TMRE) (Molecular Probes) as described previously (Susin et al., 1999b; Cregan et al., 2002). These two types of fluorescent dyes are selectively incorporated into mitochondria with an intact transmembrane potential and therefore serve as an indicator of mitochondrial depolarization. Unfixed cells were incubated with CMX-Ros at $0.25 \mu \mathrm{M}$ and TMRE at $50 \mathrm{~nm}$ in fresh media for $30 \mathrm{~min}$ at $37^{\circ} \mathrm{C}$ and washed in fresh media, and images were captured as described above. The fraction of cells maintaining mitochondrial transmembrane potential was determined by counting CMX-Ros-positive or TMREpositive cells and expressed as a percentage of total cell number in corresponding phase images.

Excitotoxicity. Cortical neurons were used in excitotoxic experiments after 14 DIV. After 2 DIV, cultures were treated with $10 \mu \mathrm{M}$ AraC to inhibit glial growth, and, at 7 DIV, they received a half change of the Neurobasal media prepared as described previously (Fortin et al., 2001). At 14 DIV, sister cultures were treated under the following conditions: (1) for NMDA, $100 \mu \mathrm{M}$ NMDA and $10 \mu \mathrm{M}$ glycine; (2) for AMPA, $100 \mu \mathrm{M}$ AMPA, $100 \mu \mathrm{M}$ cyclothiazide [6-chloro-3,4-dihydro-3-(5-norbornen-2-
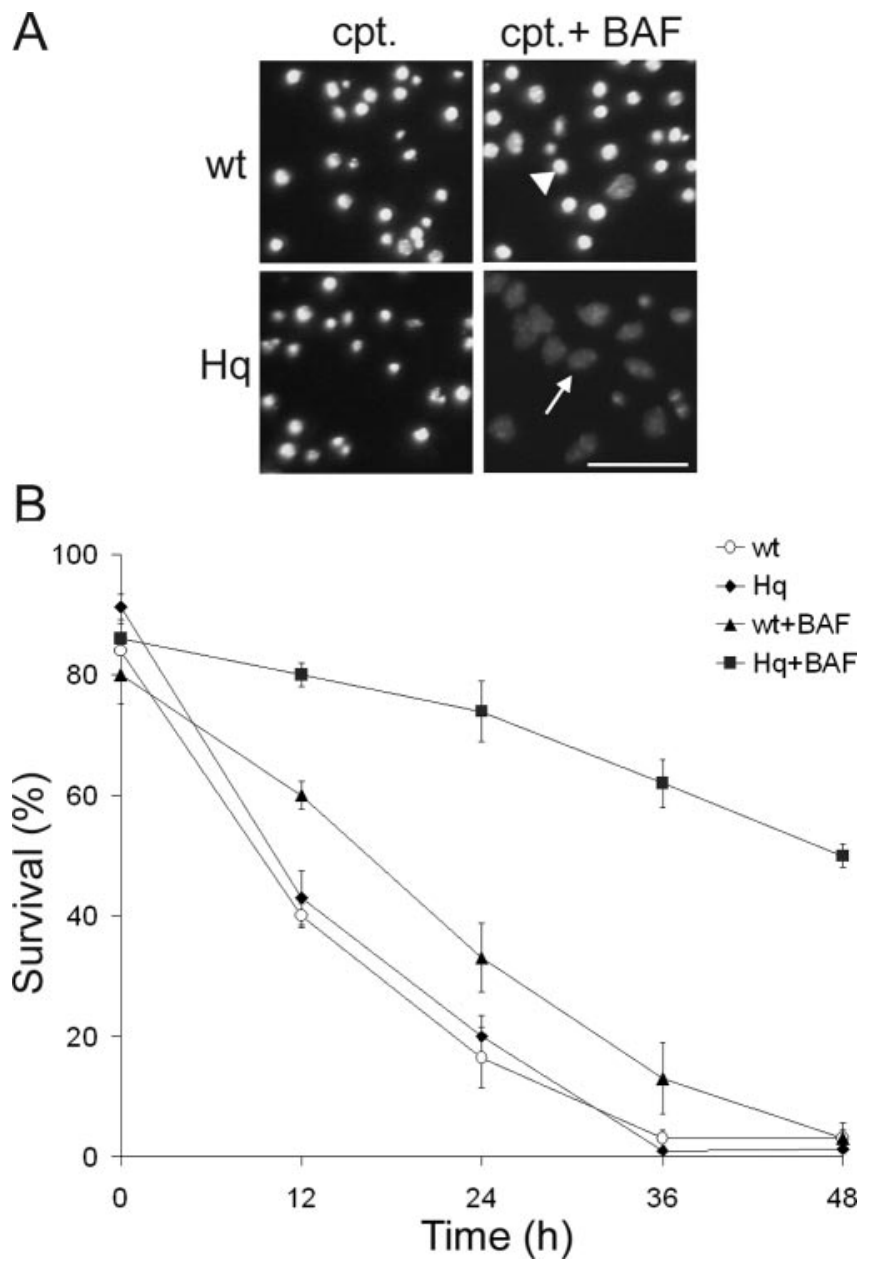

Figure 1. Reduced AIF in $\mathrm{Hq}$ mice protects neurons from camptothecin-induced neuronal cell death in the absence of caspase activity. Cortical neurons from wild-type (wt) and $\mathrm{Hq}$ littermates were treated with camptothecin (cpt.) $(10 \mu \mathrm{M})$, with or without BAF (10 $\mu \mathrm{m}) . A$, Photomicrographs of neurons after $36 \mathrm{~h}$ of treatment. Scale bar, $50 \mu \mathrm{m}$. Neurons were stained with Hoechst 33258 to assess nuclear morphology. The arrow indicates morphologically healthy nuclei, and the arrowhead indicates pyknotic condensed nuclei that denote cell death. B, Quantitative analysis of neuronal survival rate at the indicated time points after camptothecin treatment, with or without BAF. Survival as determined by nuclear morphology is reported as a percentage of live cells over the total number of cells $(n=3)$.

yl)-2H-1,2,4-benzothiazidiazine-7-sulfonamide-1,1-dioxide], and 10 $\mu \mathrm{M}$ MK-801 [(5S,10 R)-(1-5-methyl-[3,7]-10,11,-dihydro-5H-dibenzo[a,d]cyclohepten-5,10-imine]; (3) for kainic acid [(2S,3S,4R)-carboxy4-(1-methylethenyl)-3-pyrrolidineacetic acid], $100 \mu \mathrm{M}$ kainic acid, 10 $\mu \mathrm{M}$ Con A, $20 \mu \mathrm{M}$ GYKI 52466 [4-(8-methyl-9H-1,3-dioxolo [4,5$\mathrm{h}][2,3]$ benzodiazepin-5-yl)-benzenamine hydrochloride], and $10 \mu \mathrm{M}$ MK-801; (4) for glutamate, $100 \mu \mathrm{M}$ glutamate. After $1 \mathrm{~h}$, the medium was completely removed and replaced with conditioned medium from untreated cells. Cell viability was assessed as described above. All reagents, unless otherwise specified, were purchased from Sigma-Aldrich (St. Louis, MO).

Kainic acid induced seizure in vivo. Male $\mathrm{Hq}$ and wild-type littermates of at least 2 months of age were injected intraperitoneally with $30 \mathrm{mg} / \mathrm{kg}$ kainic acid (OPIKA-1; Ocean Produce, Shelburne, Nova Scotia, Canada), which was dissolved in $10 \mathrm{~mm}$ PBS in a total volume of $10 \mathrm{ml} / \mathrm{kg}$. Seizure intensity was quantified using a previously published five-point behavioral scale (McIntyre et al., 1982; Bennett et al., 1995). To minimize suffering and prevent mortality, animals were sedated with $5 \mathrm{mg} / \mathrm{kg}$ diazepam once they had reached stage 4 criteria for $5 \mathrm{~min}$. Mice were killed 4 or $7 \mathrm{~d}$ after kainic acid injection, and their brains were cut into $14 \mu \mathrm{m}$ sections as described previously (Ferguson et al., 2002). To evaluate ap- 
optotic and necrotic neuronal death, FluoroJade staining (Schmued et al., 1997), methyl green pyronine Y (MGPY) staining (Moffitt, 1994), and cresyl violet (Bennett et al., 1995) were used. FluoroJade staining was performed as described previously (Ferguson et al., 2002). In MGPY staining sections, DNA is stained blue and RNA is stained pink. Viable cells exhibited a light blue nucleus, confirming nuclear integrity, and a pink cytoplasm, indicative of RNA transcription. Damaged cells exhibited hyperchromatic nucleus and/or lack of cytoplasmic (RNA) staining (Al-Hazzaa and Bowen, 1998). In cresyl violet staining, damaged cells appeared pyknotic, eosinophilic, or hyperchromatic, with amorphous or fragmented nuclei. Healthy cells had oval nuclei, with prominent nucleoli lacking eosinophilic cytoplasm and homogenous staining (Bennett et al., 1995, 1998). All reagents, unless specified otherwise, were purchased from Sigma-Aldrich.

Quantification and statistical analysis. For in vitro studies, a minimum of 500 cells per field were scored for each treatment at indicated time points. For in vivo studies, 10 sections of similar level were counted for the FluoroJade and MGPY staining. The authors were blinded to the experiments they performed. The data represented the mean and $\mathrm{SD}$ from at least three independent experiments $(n=3)$. $p$ values were obtained using two-way ANOVA and Fisher's post hoc tests. A $p$ value $<0.05$ was considered significant.

\section{Results}

Simultaneous inhibition of AIF and caspases provides extended neuroprotection against BAX-mediated apoptotic pathways

We have shown previously that AIF is involved in neuronal cell death using microinjection of AIF-neutralizing antibodies (Cregan et al., 2002). To ask whether AIF is required for BAXdependent and BAX-independent mechanisms of neuronal cell death, we used primary neuronal cultures from $\mathrm{Hq}$ mice, which have $<20 \%$ of AIF expression (Klein et al., 2002). We first assessed the requirement of AIF in BAX-dependent apoptosis induced by DNA damage. Cortical neurons cultured from $\mathrm{Hq}$ and wild-type littermates were treated with $10 \mu \mathrm{M}$ camptothecin, and cell survival was assessed by nuclear morphology (Fig. 1A). Beginning at $12 \mathrm{~h}$ after treatment, a similar loss of survival was observed in both $\mathrm{Hq}$ and wild-type littermates (Fig. $1 \mathrm{~B}$ ). To ask whether inhibition of both mitochondrial pathways would provide added protection, total caspase activity was blocked using the broad-spectrum caspase inhibitor BAF. In the presence of BAF, $\mathrm{Hq}$ cortical neurons were more resistant to camptothecininduced apoptosis relative to $\mathrm{Hq}$ alone or BAF-treated wild-type neurons (Fig. $1 A, B$ ). Significantly, BAF-treated $\mathrm{Hq}$ neurons were still present in culture even after $48 \mathrm{~h}$, exhibiting drastically increased number of surviving neurons relative to wild type $(\mathrm{Hq}$ neurons, 60\% survival vs wild-type, 3\%) (Fig. 1B). A similar trend was also found with CGNs exposed to DNA damage (data not shown).

To assess the apoptotic pathways involved, we used a genetic approach whereby Hq/Apaf1 ${ }^{-/}$double-mutant mice were generated. In these mutant neurons, both mitochondrial-initiated pathways, caspase dependent and caspase independent, were si-

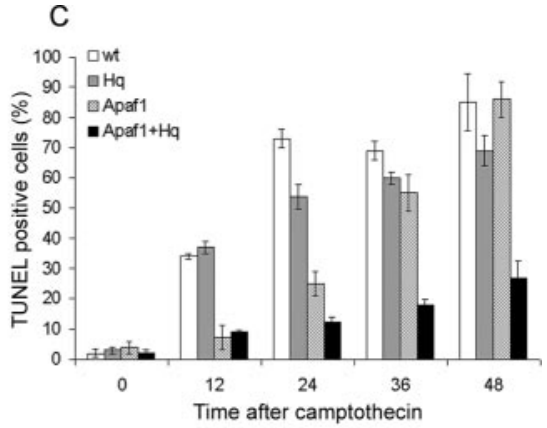

D

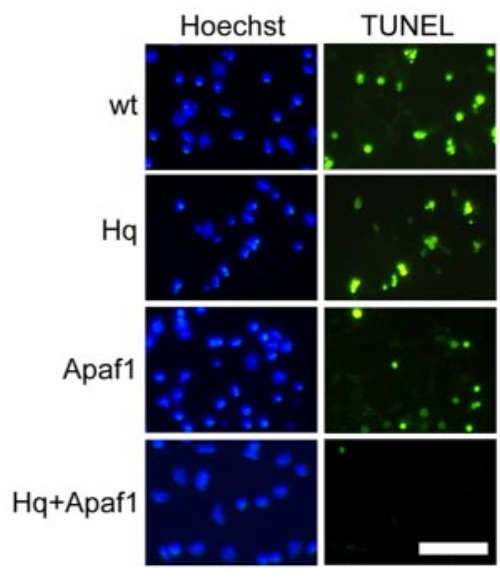
Figure 2. Caspase activation and DNA fragmentation induced by camptothecin is reduced in $A p a f 1^{-/-}$and $\mathrm{Hq} / \mathrm{Apaf1} \mathrm{T}^{-/-}$
neurons. Cortical neurons cultured from wild-type (wt), $\mathrm{Hq}, \mathrm{Apaf1}^{-/-}$, and $\mathrm{Hq} / \mathrm{Apaf1} 1^{-/-}$littermates were treated with campcoumarin)) cleavage $(n=3) . B$, Immunocytochemistry of active caspase 3 and nuclear staining by Hoechst at $24 \mathrm{~h}$. C, Quantification of TUNEL staining $(n=3)$. D, TUNEL staining and nuclear staining by Hoechst at $24 \mathrm{~h}$. Scale bar, $50 \mu \mathrm{m}$.

multaneously impaired. We have shown previously that Apaf1 $^{-/-}$neurons remained viable only in the first $24 \mathrm{~h}$ after camptothecin treatment, after which survival rapidly decreased. This delayed death in Apaf1 ${ }^{-1-}$ cells was caspase independent and could not be inhibited by BAF (Cregan et al., 2002). Neurons were cultured from $H q / A p a f 1^{-1-}$ double-mutant embryos that were viable up to E15.5, similar to that seen with Apaf1 ${ }^{-/-}$alone. As described previously, neurons from $\mathrm{Hq}$ mice revealed an $\sim 80 \%$ reduction in AIF protein expression (result not shown). In wild-type and $\mathrm{Hq}$ neurons, the DNA-damaging agent camptothecin induced caspase activation, as indicated by DEVD cleavage, a fluorometric caspase substrate assay (Fig. $2 \mathrm{~A}$ ) and active caspase 3 immunohistochemistry (Fig. 2B). Consistent with our previously published work (Fortin et al., 2001), no significant caspase activation could be detected in $\mathrm{Apafl}^{-1-}$ and $\mathrm{Hq} / \mathrm{Apaf1}^{-1-}$ neurons (Fig. $2 A, B$ ). Following a similar trend, TUNEL staining was similar in wild-type and $\mathrm{Hq}$ neurons, whereas Apaf1 deficiency resulted in a transient reduction in TUNEL staining evident at 12 and $24 \mathrm{~h}$. Previously, we have shown that the level of DNA fragmentation in Apaf1 ${ }^{-1-}$ neurons revealed by TUNEL staining is similar with or without the addition of the pan-caspase inhibitor BAF. This suggests that DNA fragmentation revealed by TUNEL staining in Apaf1 ${ }^{-/-}$neurons results from caspase-independent mechanisms (Cregan et al., 2002). The double Hq/Apaf1 ${ }^{-/-}$mutants exhibited a sustained delay in apoptotic DNA fragmentation such that only $27 \%$ of cells were TUNEL positive relative to $85-86 \%$ seen in wild-type and Apafl $^{-1-}$ neurons (Fig. 2C). These data demonstrate a striking and sustained reduction in apoptotic 
A

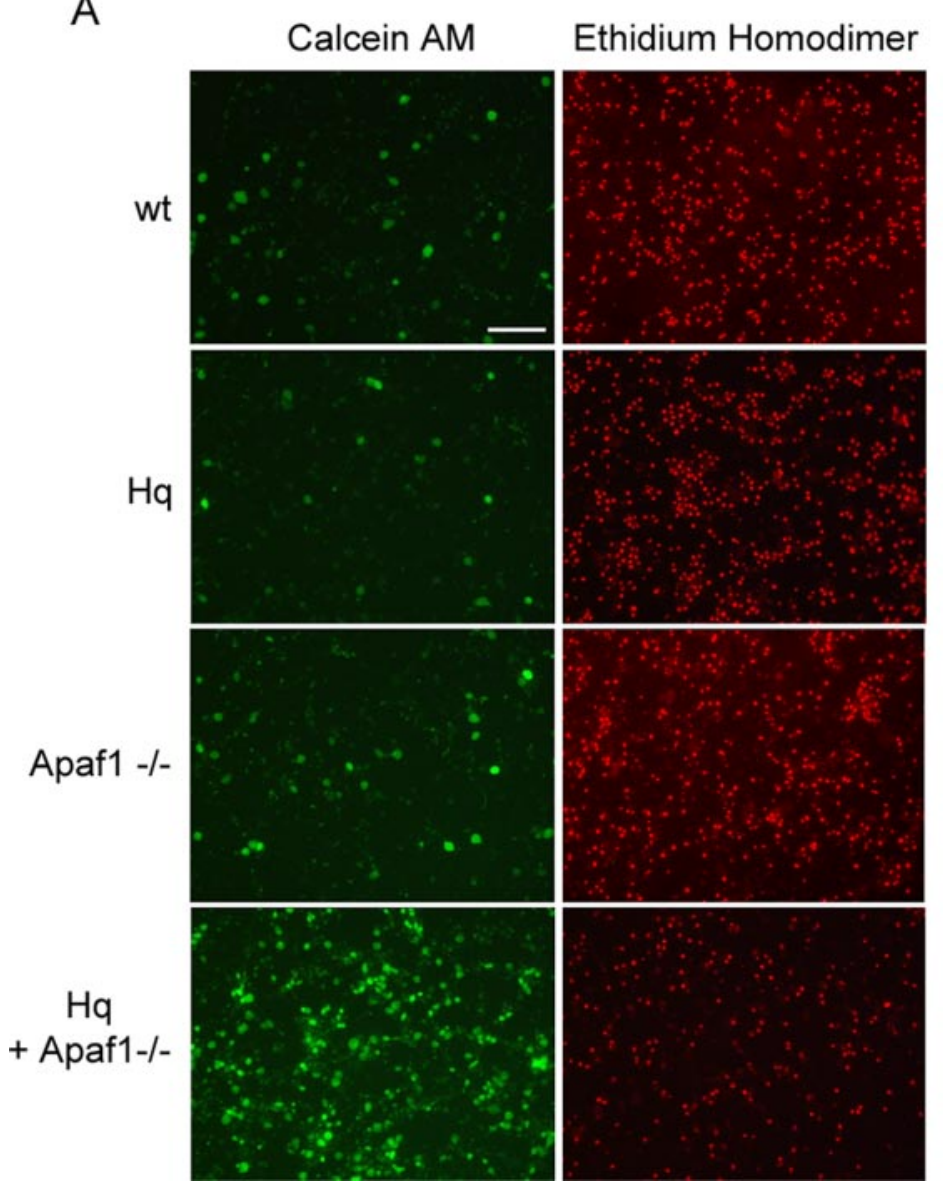

B

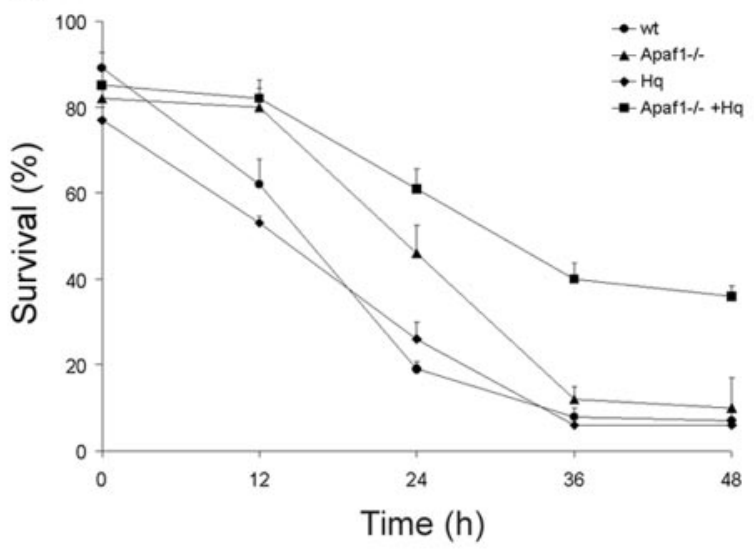

C

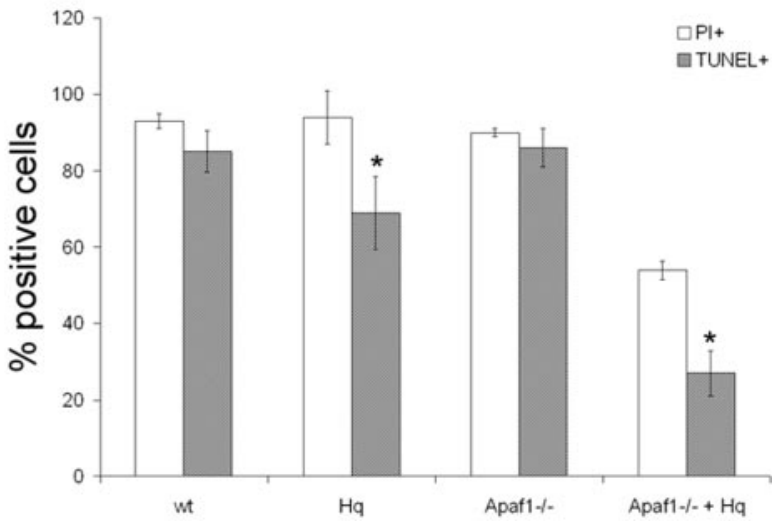

Figure 3. Inhibition of caspases and AIF in $\mathrm{Hq} \mathrm{Apaf1}^{-/-}$double mutants increases the survival of cortical neurons against camptothecin-induced cell death. Cortical neurons from wild-type (wt), Apaf1 $^{-/-}, \mathrm{Hq}$, and $\mathrm{Hq} / \mathrm{Apaf1}^{-/-}$littermates were treated with camptothecin (10 $\left.\mu \mathrm{m}\right)$. Neuronal survival was measured by live/dead assay. Live cells exhibit staining for calcein-AM activity (green fluorescence), whereas dead cells stain positive for ethidium homodimer (red fluorescence). $A$, Neurons after $36 \mathrm{~h}$ of camptothecin treatment with live/dead staining. Scale bar, $100 \mu \mathrm{m}$. $B$, Quantitative analysis of survival rate measured by live/dead assay after camptothecin treatment $(n=3)$. C, Quantitative analysis of propidium iodide-positive (PI+) and TUNEL-positive (TUNEL + ) neurons $48 \mathrm{~h}$ after camptothecin treatment $(n=3) .{ }^{*} p<0.01$ compared with $\mathrm{PI}+$.

DNA fragmentation in neurons in which both mitochondrial apoptotic pathways are impaired.

Previous studies have suggested that AIF may play a key role in facilitating DNA fragmentation during apoptosis. Because TUNEL staining and DNA condensation was severely reduced in Hq/Apaf1 ${ }^{-/-}$neurons, cell viability was evaluated by two alternative methods that do not rely on DNA fragmentation. First, live/dead staining was used, which measures the following: (1) cell viability, by the enzymatic conversion of the nonfluorescent calcein-AM to the fluorescent calcein in healthy cells, simultaneously with (2) cell death by PI uptake to evaluate loss of membrane integrity during apoptosis. Consistent with DNA fragmentation assays, cell viability was highest in $\mathrm{Hq} / \mathrm{Apaf1^{-/- }}$ double mutants, and this enhanced viability was sustained for at least $48 \mathrm{~h}$ (Hq/Apaf1 ${ }^{-1-} 36 \%$ survival at $48 \mathrm{~h}$ vs $6-10 \%$ for all other genotypes) (Fig. $3 A, B$ ). Because AIF through association with endonucleases is proposed to be responsible for DNA fragmentation during apoptosis (Wang et al., 2002; Parrish et al., 2003), we asked the question as to what proportion of the $\mathrm{Hq}$ neurons that go on to die exhibit DNA fragmentation. To assess this, we compared the number of cells exhibiting DNA fragmentation with the number of dying cells as determined by PI staining. Our results revealed that cells lacking AIF exhibited a defect in DNA fragmentation during apoptosis. Specifically, Hq/Apaf1 ${ }^{-/-}$double mutants revealed a $54 \%$ loss of viability based on PI staining, but only $27 \%$ of total cells exhibited DNA fragmentation (TUNEL) at $48 \mathrm{~h}$ (Fig. 3C). Thus, of the dying cells, only $50 \%$ (27\% TUNEL/54\% PI) exhibited DNA fragmentation relative to 91\% (85\% TUNEL/93\% PI) seen in wild-type neurons. Indeed, neurons carrying the $\mathrm{Hq}$ mutant alone exhibited reduced TUNEL staining $(60 \%$ of dying cells) despite the presence of intact caspase pathways (Figs. $2 B, 3 C$ ). These results demonstrate the following: (1) based on PI staining, neurons impaired in both mitochondrial pathways exhibit sustained viability even after $48 \mathrm{~h}$ after camptothecin treatment; and (2) of the cells that go on to die in $\mathrm{Hq} / \mathrm{Apaf1^{-/- }}$ neurons, there is a striking reduction of DNA fragmentation during cell death. These results strongly support a function for AIF in caspase-independent DNA fragmentation during the execution phase of cell death.

As a second measure of cell viability, independent of DNA fragmentation, we evaluated the retention of mitochondrial membrane potential. The indicator dye TMRE, which can only be taken up by mitochondria with an intact membrane potential, was used. At time 0, neurons from all the genotypes exhibited similar levels of TMRE staining (83-86\%), indicating that mitochondrial function of the different genotypes is similar. Consistent with our results obtained by PI staining, many of these double-mutant neurons were found to retain their mitochondrial membrane potential for as long as $48 \mathrm{~h}$ after camptothecin treatment. Neurons derived from the other genotypes (wild-type, 
A

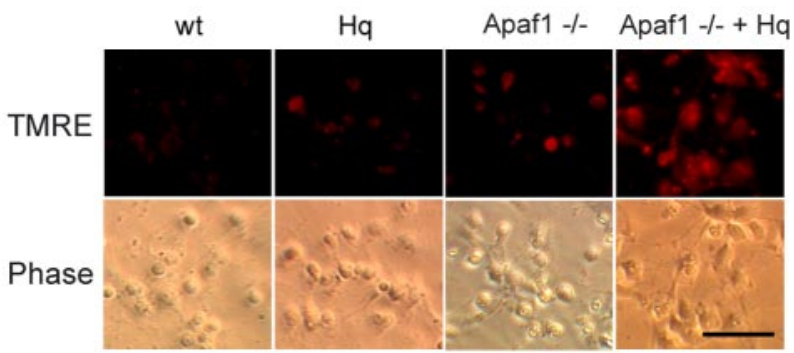

B

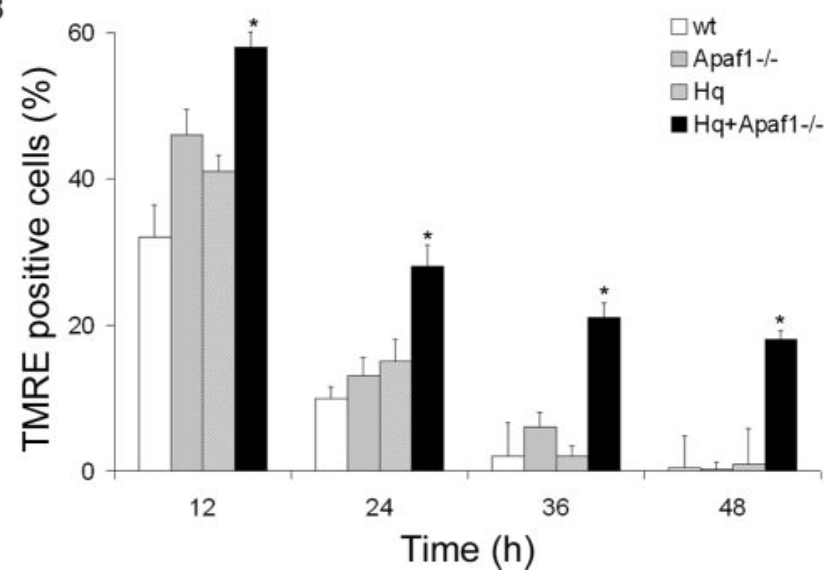

Figure 4. A higher proportion of $\mathrm{Hq} / \mathrm{Apaf1}^{-1-}$ double-mutant neurons retain mitochondrial membrane potential after camptothecin treatment. Cortical neurons from wild-type (wt), Apaf1 $^{-/}, \mathrm{Hq}$, and $\mathrm{Hq} / \mathrm{Apaf1}^{-/-}$littermates were treated with camptothecin $(10 \mu \mathrm{m})$, and mitochondrial membrane potential was assessed by TMRE, which only incorporates into mitochondria with intact membrane potential. $A$, Neurons $36 \mathrm{~h}$ after camptothecin treatment. Scale $\mathrm{bar}, 50 \mu \mathrm{m}$. Phase, Phase contrast microscopy. B, Quantitative analysis of neurons with positive TMRE staining, which indicates intact mitochondrial membrane potential at the indicated times. TMRE-positive cells are reported as a percentage of stained cells over the total number of cells $(n=3)$.

$H q$, and $\left.A p a f 1^{-/-}\right)$showed a complete loss of mitochondrial polarization by this time (Fig. 4A,B). A similar trend was also observed using Mitotracker Red CMX-Ros, another dye for intact mitochondrial potential (data not shown). These results demonstrate that, by blocking both mitochondrial pathways, the caspase-dependent pathway (by BAF treatment or Apaf1 ${ }^{-/-}$) and the AIF pathway (by $\mathrm{Hq}$ mutation), neurons can be significantly protected against DNA damage-induced cell death.

\section{Neurons with reduced AIF are more resistant to glutamate- induced excitotoxic cell death}

Excitotoxic neuronal cell death is one of the mechanisms that causes major damage after acute brain injury, such as stroke or trauma (Arundine and Tymianski, 2003; Yuan et al., 2003). Excitotoxicity can occur independent of BAX and caspase activation (Miller et al., 1997; Dargusch et al., 2001). To confirm that BAX is not involved in excitotoxic cell death, $B a x^{-/-}$and wild-type neurons were exposed to $100 \mu \mathrm{M}$ glutamate or $200 \mu \mathrm{M}$ NMDA. After $24 \mathrm{~h}$, cell viability was measured by MTT assay. BAX deficiency did not protect cortical neurons against excitotoxicity induced by $100 \mu \mathrm{m}$ glutamate or $200 \mu \mathrm{M}$ NMDA (Fig. 5A). Similarly, BAX deficiency had no effect against glutamate-induced cell death in CGNs (Fig. 5A). To determine whether caspases are activated during glutamate-mediated cell death, DEVD cleavage was measured at 12 and $24 \mathrm{~h}$ after treatment. No significant DEVD cleavage was detected during excitotoxic cell death compared with camptothecin treatment (Fig. 5B). Similarly, immunohistochemistry using active caspase 3 antibody did not reveal caspase 3 activation. This is in contrast to the robust staining observed after treatment of these same neurons with camptothecin (Fig. 5D). Consistent with the absence of caspase involvement, treatment of cortical neurons with BAF provided no protection against cell death induced by glutamate receptor activation (Fig. 5C). Despite the lack of BAX and caspase involvement in glutamate-mediated cell death, wild-type neurons undergoing this caspaseindependent cell death exhibited DNA fragmentation as determined by TUNEL staining. This was drastically reduced in $\mathrm{Hq}$ neurons (Fig. 5E), suggesting that the absence of AIF may protect against this mechanism of cell death.

Next, we asked whether AIF is translocated to the nucleus during glutamate-induced cell death. Wild-type cortical neurons and CGNs were infected with a recombinant adenoviral vector expressing green fluorescent protein (GFP)-tagged AIF and treated with $100 \mu \mathrm{M}$ glutamate. AIF localization was assessed after $24 \mathrm{~h}$ using confocal microscopy to assess double labeling with the mitochondrial marker CoxIV. In healthy cells, GFP-tagged AIF was mitochondrial (Fig. $6 \mathrm{~A}$ ); however, $24 \mathrm{~h}$ after glutamate exposure, $>70 \%$ of GFP-positive cortical neurons exhibited nuclear translocation of AIF (Fig. 6A,B). Translocation was also observed in CGNs (Fig. 6C). A similar trend was also observed by immunostaining for endogenous AIF after glutamate treatment in cortical neurons (Fig. 6A). To assess viability of $\mathrm{Hq}$ and wild-type neurons after glutamate exposure, nuclear condensation was evaluated by Hoechst (Fig. 7B), and survival was measured by live/dead assay (Fig. 7A). At all time points after transient application of $100 \mu \mathrm{m}$ glutamate, $\mathrm{Hq}$ cortical neurons exhibited significantly higher survival rates relative to neurons cultured from wild-type littermates. Specifically, at $48 \mathrm{~h}, 40.3 \%$ of $\mathrm{Hq}$ cortical neurons were still viable relative to only $7.6 \%$ of wild-type littermates. This glutamate-induced neurotoxicity was completely inhibited by MK-801, demonstrating that toxicity occurs specifically through activation of NMDA receptors (Fig. 7B). Because previous studies by Klein et al. (2002) indicated that the sensitivity to glutamate after AIF depletion differed between cortical and cerebellar neurons, we also conducted this experiment in CGNs. Our results show a similar trend regardless of the neuronal cell type (CGNs, 45 vs $24 \%$ ) as indicated by live/dead assay (Fig. $8 A, B$ ) and nuclear morphology (data not shown).

Previous studies examining high-dose treatment with glutamate (1 mM) revealed that $\mathrm{Hq}$ CGNs were not resistant but instead exhibited increased sensitivity, whereas $H q$ cortical neurons were not different from controls (Klein et al., 2002). To ask whether AIF deficiency renders neuron more sensitive to high levels of glutamate treatment, a dose-response curve was conducted $(0.1-1.0 \mathrm{~mm}$ glutamate) with both CGNs and cortical neurons. Using either the live/ dead assay or nuclear condensation, the reduction of AIF resulted in protection against glutamate-induced cell death up to $0.75 \mathrm{~mm}$. There was no difference between $\mathrm{Hq}$ and wild-type littermate controls at concentrations higher than $0.75 \mathrm{~mm}$ (Fig. 7C). A similar trend was also observed using CGNs (data not shown). Together, our results reveal AIF as a cell death executor in mechanisms involving acute neuronal injury, such as excitotoxicity.

\section{Hq neurons are more resistant to NMDA- and kainic acid-} induced cell death but not AMPA

To determine which receptors recruit AIF function during excitotoxicity, specific agonists for the different glutamate receptors were assessed over a time course of $48 \mathrm{~h}$ in both cortical neurons and CGNs. Agonists to the three ionotrophic glutamate receptors were tested, including NMDA, AMPA, and kainic acid (Dingledine et al., 1999). Here, we asked whether AIF recruitment to the death cascade occurred with all or only a subset of ionotrophic 

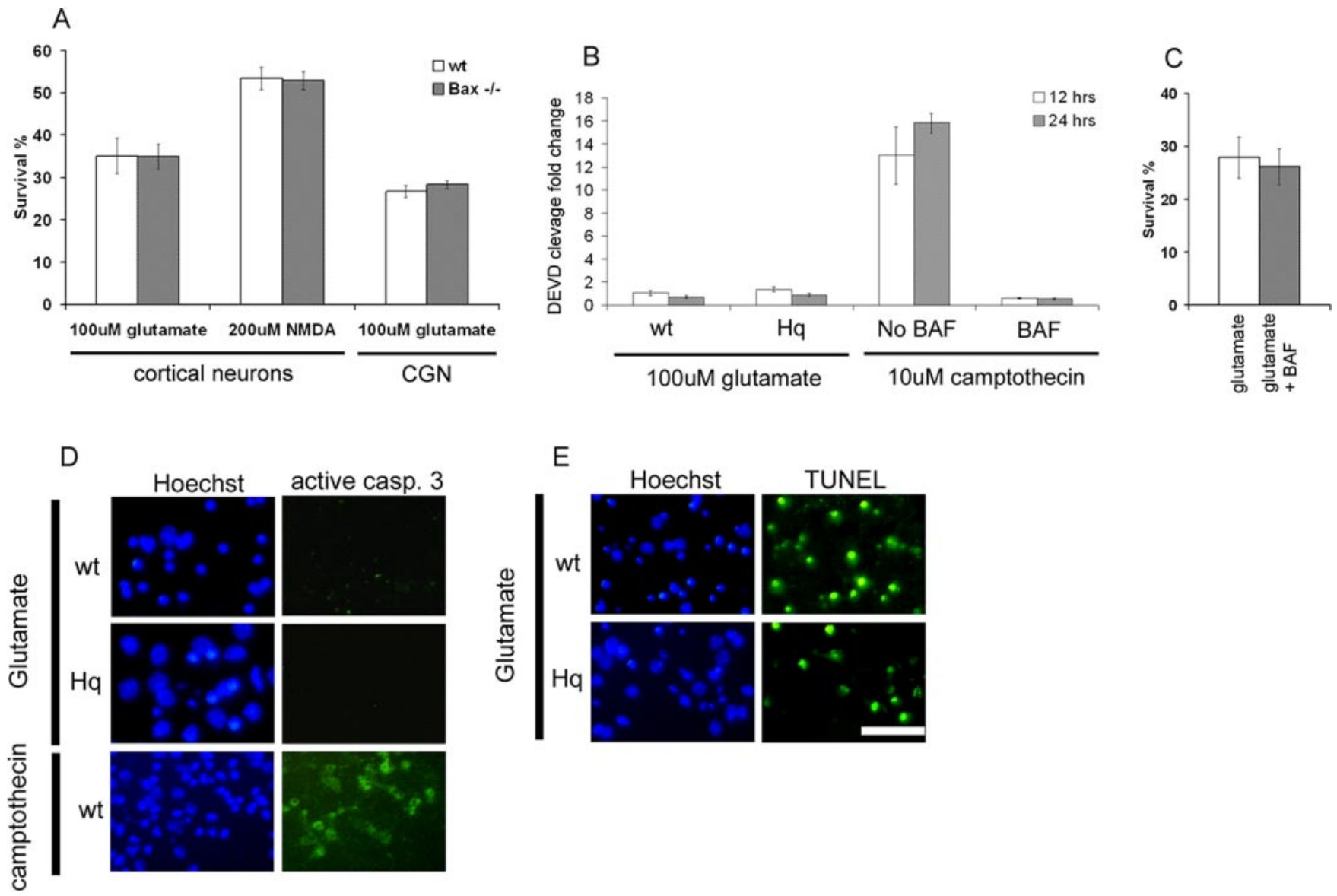

Figure 5. Excitotoxicity-induced neuronal cell death is BAX and caspase independent. $A$, Quantification of survival by MTT assay in cortical neurons and CGNs from BAX-deficient and wild-type (wt) littermates after $24 \mathrm{~h}$ of treatment with $100 \mu \mathrm{m}$ glutamate and $200 \mu \mathrm{m} \mathrm{NMDA} \mathrm{for} \mathrm{cortical} \mathrm{neurons} \mathrm{and} 100 \mu \mathrm{m}$ glutamate for CGNs $(n=4)$. B, Caspase 3 activity is measured by DEVD-AFC cleavage in wild-type and $\mathrm{Hq}$ cortical neurons after $24 \mathrm{~h}$ of treatment with $100 \mu \mathrm{m}$ glutamate. Camptothecin-treated wild-type neurons with or without BAF are used as positive and negative controls, respectively $(n=3)$. C, MTT assay for wild-type neurons treated with $100 \mu \mathrm{m}$ glutamate in the presence or absence of $50 \mu \mathrm{m} \mathrm{BAF}(n=3)$. Note that BAF does not provide protection after exposure to glutamate. D, Active caspase 3 immunohistochemistry $24 \mathrm{~h}$ after $100 \mu \mathrm{m}$ glutamate treatment and camptothecin-treated wild-type cells were used as a control. E, TUNEL staining of cortical neurons $24 \mathrm{~h}$ after $100 \mu \mathrm{m}$ glutamate treatment, indicating DNA fragmentation in the absence of caspase. Scale bar, $50 \mu \mathrm{m}$.

glutamate receptors. Cortical neurons from $\mathrm{Hq}$ and wild-type littermates were treated with AMPA, kainic acid, and NMDA with the appropriate coagonist (glycine for NMDA treatment) and desensitizing inhibitors (cyclothiazide for AMPA and Con A for kainic acid) (Huettner, 1990; Wong and Mayer, 1993). For AMPA and kainic acid treatments, MK-801 was added to prevent NMDA receptor activation, and, for kainic acid treatment, GYKI 52466 was added to prevent AMPA receptor activation (Huettner and Bean, 1988; Paternain et al., 1995). Hq cortical neurons were more resistance to $100 \mu \mathrm{M}$ NMDA treatment (Fig. 9A) and 100 $\mu \mathrm{M}$ kainic acid treatment (Fig. $9 B$ ), which was similar to the response obtained with $100 \mu \mathrm{M}$ glutamate treatment (Fig. 7A,B). The NMDA-induced neurotoxicity, as in the case of glutamate, was inhibited by MK-801, confirming NMDA receptor specificity (data not shown). Reduced levels of AIF did not protect against all ionotrophic glutamate receptor agonists, because $\mathrm{Hq}$ neurons exposed to AMPA exhibited a similar rate of cell death as that seen with wild-type littermates (Fig. 9C). Lower dosages of $50 \mu \mathrm{M}$ AMPA were also tested, and, unlike NMDA and kainic acid treatment, $H q$ neurons were not protected against exposure to AMPA (supplemental Fig. 1, available at www.jneurosci.org as supplemental material). Supporting the lack of AIF involvement in AMPA-induced cell death, AMPA did not induce AIF translocation (Fig. 9D), in contrast to that seen after glutamate exposure (Fig. 6). This was consistent with a recent study examining AIF translocation in PARP-deficient mice (Wang et al., 2004). Of the dying $H q$ neurons, only 69\% for NMDA (29\% TUNEL/47.78\% PI) and 52\% for kainic acid (22.3\% TUNEL/43\% PI) exhibited DNA fragmentation relative to $98 \%$ for NMDA (68.6\% TUNEL/ $70.45 \% \mathrm{PI})$ and $97 \%$ for kainic acid (63.3\% TUNEL/65.2\% PI) seen in wild-type neurons (Fig. $9 E$ ). This suggests that, similar to camptothecin-treated $\mathrm{Hq} / \mathrm{Apaf1^{-/- }}$ neurons (Fig. $3 \mathrm{C}$ ), there is a drastic reduction of DNA fragmentation in excitotoxin-treated $H q$ neurons. These results strongly support that AIF is a key factor in DNA fragmentation and neuronal cell death during excitotoxicity.

\section{Reduced AIF levels confers increased resistance to} hippocampal damage resulting from kainic acid-induced seizure

Because $\mathrm{Hq}$ cortical and CGNs are more resistant to excitotoxic injury in vitro, we next asked whether $\mathrm{Hq}$ neurons are also more resistant to excitotoxicity in vivo using a kainic acid seizure model. In these experiments, CA3 hippocampal damage was assessed after kainic acid-induced seizure (Strain and Tasker, 1991). Adult mice received intraperitoneal injections of $30 \mathrm{mg} / \mathrm{kg}$ kainic acid and were allowed to develop stage 4 seizures (Bennett et al., 1995). Both $\mathrm{Hq}$ mice and wild-type littermate controls were tested in pairs and equally developed stage 4 seizures. Damage in the hippocampal CA3ab region was assessed by MGPY, cresyl 
A
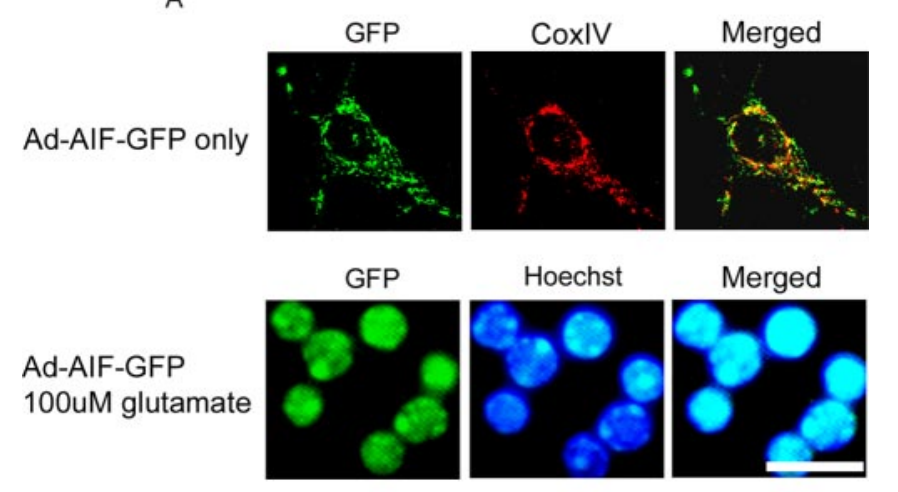

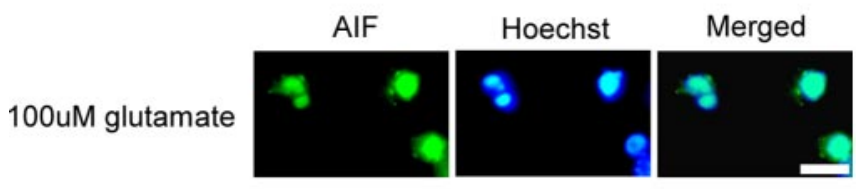
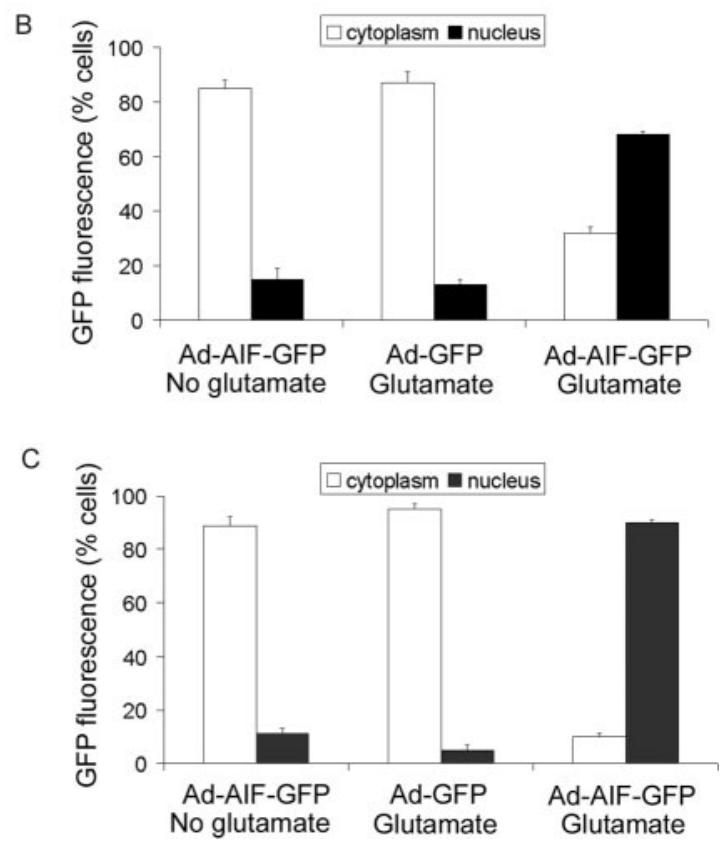

Figure 6. AIF translocates to the nucleus during glutamate-induced cell death. $A$, Cortical neurons from wild-type mice were infected with recombinant adenoviral vector (Ad) containing GFP-tagged AlF and were treated with glutamate $(100 \mu \mathrm{m})$ for $1 \mathrm{~h}$. After $24 \mathrm{~h}$, cells were fixed and stained with Hoechst for nucleus and CoxVI antibody for mitochondria, and GFP fluorescence was observed. Translocation of endogenous AIF was also assessed using AIF antibody and Hoechst staining. Scale bar, $10 \mu \mathrm{m}$. B, Quantitative analysis of GFP fluorescence in the nucleus in cortical neurons $(B)$ and $C G N s(C)(n=3)$.

violet, and FluoroJade staining at 4 and $7 \mathrm{~d}$ after treatment. $\mathrm{Hq}$ mice exhibited significantly less damage in the $\mathrm{CA} 3$ ab region after $4 \mathrm{~d}$ after kainic acid-induced seizure (Fig. 10A). Resistance to injury in $\mathrm{Hq}$ mice was indicated by increased numbers of healthy cells shown by MGPY staining in the CA3ab region (Fig. 10A,B) and significantly fewer cells with apoptotic morphology, as revealed by cresyl violet staining (Fig. $10 \mathrm{~A}$ ). $\mathrm{Hq}$ mice also exhibited fivefold less FluoroJade-positive cells relative to littermate controls (Fig. 10 A, C). To ask whether $\mathrm{Hq}$ mice exhibited long-term protection, hippocampal neuron survival was also assessed 1 week after kainic acid injection. Whereas neuroprotection in $\mathrm{Hq}$ mice was still significant at $7 \mathrm{~d}$, the number of viable cells was decreased with a corresponding increase in the number of
FluoroJade-positive cells (Fig. 10 B,C). This gradual decrease in cell viability was likely attributable to the residual AIF expression (20\%) in $\mathrm{Hq}$ neurons that may allow the death pathway to proceed at an attenuated rate. These in vivo results support our in vitro findings that a reduction of AIF expression in neurons provides protection against excitotoxic injury.

In summary, using mice carrying the $\mathrm{Hq}$ mutation, we have shown that AIF plays a crucial role in both the BAX-dependent and BAX-independent cell death cascades involved in neuronal injury. After BAX recruitment after DNA damage, AIF is involved in the caspase-independent death cascade and functions to facilitate DNA fragmentation. Furthermore, AIF is also directly involved in Bax-independent death pathways, such as excitotoxicity. In excitotoxic neuronal cell death, AIF is specifically recruited after activation of NMDA and kainic acid receptors. These results demonstrate that AIF plays a key role in executing cell death in multiple mechanisms of acute neuronal injury.

\section{Discussion}

In this study, we used $\mathrm{Hq}$ mice that have severely reduced AIF levels to study the role of AIF in neuronal injury. First, we showed that, in the absence of caspase activity, $\mathrm{Hq}$ neurons exhibited extended protection against camptothecin-induced DNA damage well beyond that seen by caspase inhibition alone. The surviving $\mathrm{Hq}$ neurons with caspase inhibition retained their mitochondrial membrane potential relative to wild-type, Apaf1 ${ }^{-1}$, and $\mathrm{Hq}$ mutants. Second, $\mathrm{Hq}$ neurons were more resistant to glutamate-induced excitotoxicity, particularly through NMDA and kainic acid receptors but not AMPA receptors. Consistent with AIF recruitment in excitotoxicity, adult $\mathrm{Hq}$ mice exhibited less damage in the hippocampus after kainic acid-induced seizure in vivo. These studies demonstrate an important role for AIF in multiple cell death pathways and suggest that AIF may provide a valuable therapeutic target for the treatment of acute brain injury.

\section{Apaf1-deficient $\mathrm{Hq}$ neurons exhibit sustained protection against BAX-mediated apoptosis}

Previous studies have shown that inhibition of caspase activity can delay the onset of neuronal cell death. Specifically, studies using animal models of stroke have revealed a striking short-term protection after caspase inhibition. This protection is only transient, however, because at extended time points, neuronal death still ensues at a delayed rate despite inhibition of caspase activity (Cregan et al., 1999, 2002; Fortin et al., 2001). Similarly, the use of caspase inhibitors in an animal model of stroke have again shown only short-term protection against apoptosis, but, after extended time courses, death occurs nonetheless (Endres et al., 1998). It is therefore evident that caspase-independent pathways can compensate when the caspase cascade is blocked. Consistent with this, we have shown previously that AIF is the key factor in neuronal apoptosis when caspase is inhibited, either by BAF or in Apaf1 ${ }^{-\prime}$ --deficient animals (Cregan et al., 2002). Microinjection of AIF antibodies can significantly rescue this form of caspaseindependent cell death. AIF has also been shown to translocate in in vivo animal models of neurodegeneration, such as focal ischemia (Zhu et al., 2003; Komjati et al., 2004; Plesnila et al., 2004). Because Aif $^{-1-}$ animals are early embryonic lethal, the role of AIF in neuronal cell death has not been directly examined. In this report, we studied the role of AIF using $\mathrm{Hq}$ mice in which AIF expression is reduced by $>80 \%$ (Klein et al., 2002). This provides the opportunity to directly examine the role of AIF in neuronal cell death and the extent of protection when both caspase- 
A

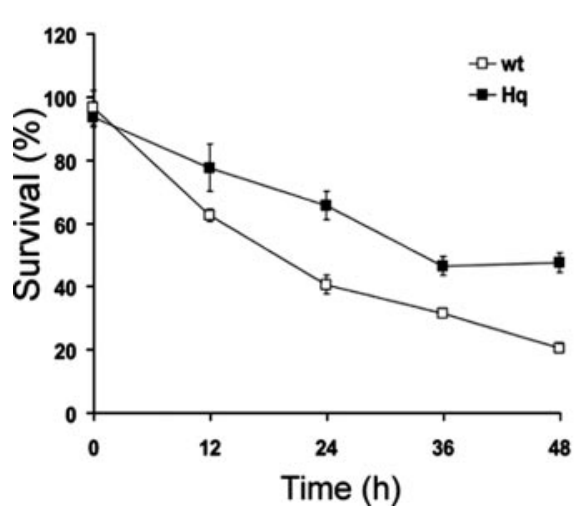

B

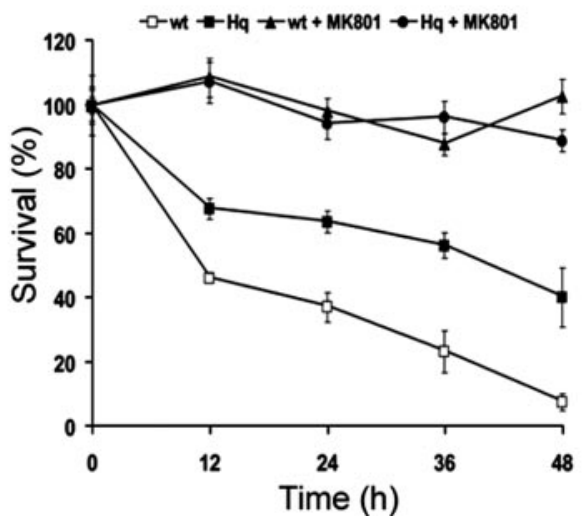

C

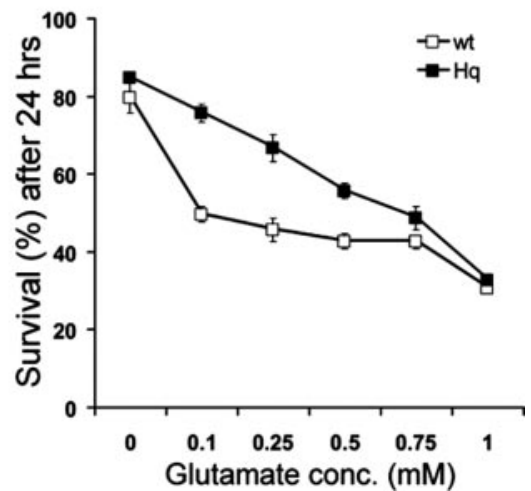

Figure 7. Hq cortical neurons are more resistant to excitotoxicity induced by glutamate. Cortical neurons (14 DIV) from wild-type (wt) and $\mathrm{Hq}$ littermates were treated with glutamate (100 $\mu \mathrm{m}$ ) for $1 \mathrm{~h} . A$, Quantitative analysis of neuronal survival rate by live/dead assay at the indicated time points after glutamate treatment $(n=3)$. B, Quantitative analysis of neuronal survival rate by nuclear morphology revealed by Hoechst staining at the indicated time points after glutamate treatment $(n=3)$. Survival is reported as a percentage of cells with morphologically healthy nuclei over the total number of cells. C, Quantitative analysis of cortical neuron survival with increasing glutamate concentration after $24 \mathrm{~h}(n=3)$.

A

\section{A} Calcein AM Ethidium Homodimer

wt
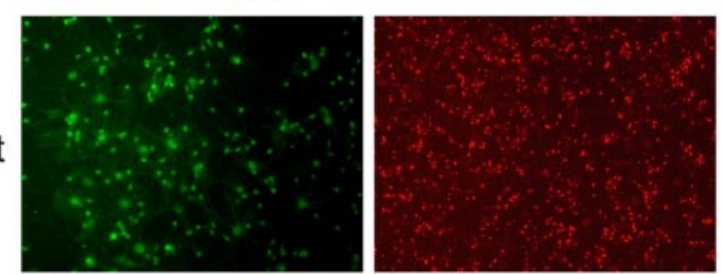

$\mathrm{Hq}$
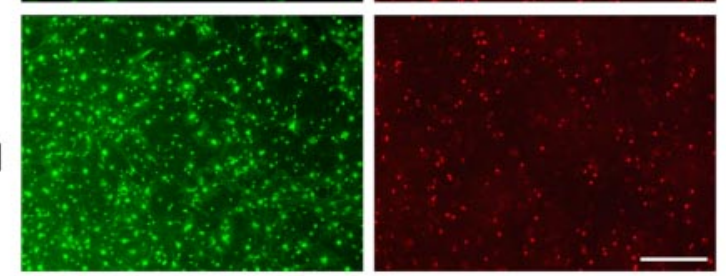

B

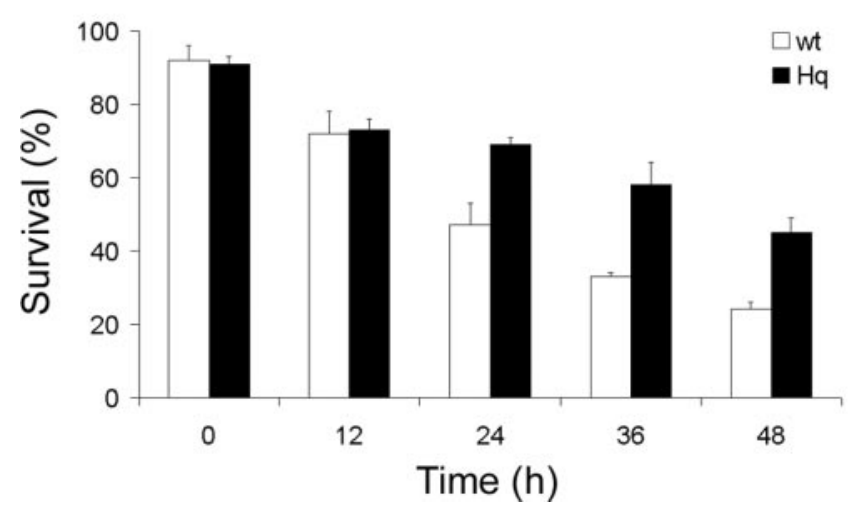

Figure 8. $\mathrm{Hq}$ CGNs are more resistant to excitotoxicity induced by glutamate. CGNs (14 DIV) from wild-type (wt) and $\mathrm{Hq}$ littermates were treated with glutamate $(100 \mu \mathrm{m})$ for $1 \mathrm{~h}$. Neuronal survival was determined with live/dead assay. $A$, Photomicrographs of neurons $36 \mathrm{~h}$ after glutamate treatment. Scale bar, $250 \mu \mathrm{m}$. B, Quantitative analysis of survival rate at the indicated time points after glutamate treatment $(n=3)$.

dependent and -independent pathways are blocked. In the present studies, we first show that, in the absence of caspases (by BAF application), $\mathrm{Hq}$ neurons were more resistant to camptothecin-induced DNA damage apoptosis. More signifi- cantly, during DNA damage-induced apoptosis, we also demonstrate extended protection in $H q / A p a f 1^{-/-}$double-mutant neurons in which the mitochondrial-initiated caspase-dependent and -independent pathways are blocked (Fig. $3 A, B$ ). Importantly, of the Hq/Apaf1 ${ }^{-/-}$neurons that go on to die, there is dramatically less DNA fragmentation as determined by TUNEL staining relative to that seen in neurons with Apaf1 $1^{-1-}$ mutations alone or in wild-type littermates. These results demonstrate that AIF plays an important role in the regulation of DNA degradation during injury-induced apoptosis (Fig. 2D, 3C).

Our data also indicate that $\mathrm{Hq} / \mathrm{Apaf1^{-/- }}$ mutant cells reveal a higher percentage of cells containing mitochondria with intact membrane potential, suggesting that they are still viable and metabolically active (Fig. $4 A, B$ ). These results show that, by inhibiting both caspase-dependent and caspase-independent death pathways, neurons are provided sustained protection against Bax-mediated cell death that extends well beyond that resulting from inhibition of caspase alone. This protection was particularly striking considering that these neurons retain $\sim 20 \%$ of the wild-type AIF activity, which should still allow some residual apoptotic signaling to occur. It is unlikely that this protection is attributable to other unknown genetic defects in the Hq mice because a similar level of protection against camptothecin-induced death was observed in double-mutant neurons cultured from mice carrying conditional AIF mutations on an Apaf1 ${ }^{-/-}$background (E. C. C. Cheung and R. S. Slack, unpublished data). Although mice with $\mathrm{Hq}$ alone exhibited reduction in DNA fragmentation, there is no long-term protection compared with $\mathrm{Hq} /$ Apaf $1^{-1-}$ double mutants. This may be attributable to the fact that the presence of caspases in these cells overwhelms the protection conferred by AIF reduction alone. Recently, other studies in nonneuronal cell lines (Arnoult et al., 2002, 2003) and rat cortical neurons (Lang-Rollin et al., 2003) suggested that AIF requires caspases to be released from mitochondria, in contrast to other studies (Susin et al., 1999a,b, 2000; Daugas et al., 2000; Cregan et al., 2002; Yu et al., 2002) that clearly indicate that AIF translocation can occur independent of caspases. This discrepancy may be attributable to the fact that different cell types recruit different mechanisms of cell death depending on the type of injury sustained. Our previous (Cregan et al., 2002) and present studies directly demonstrate that the caspaseindependent signaling cascade, in which AIF is a key determinant, clearly plays a role in BAX-mediated neuronal cell death. 


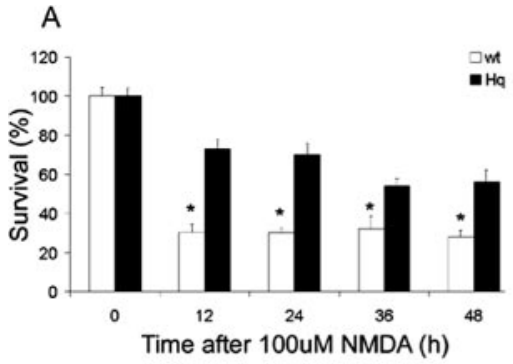

Di

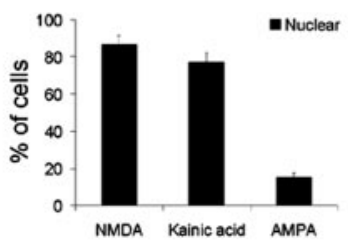

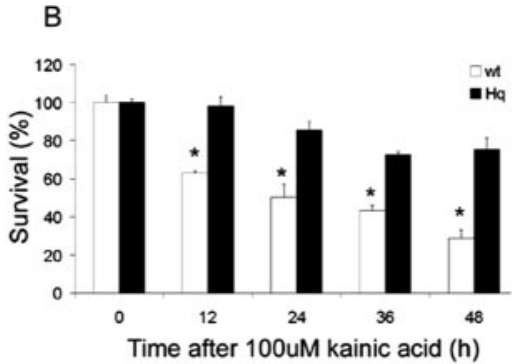

D ii

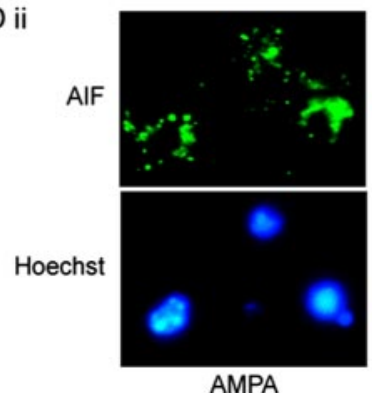

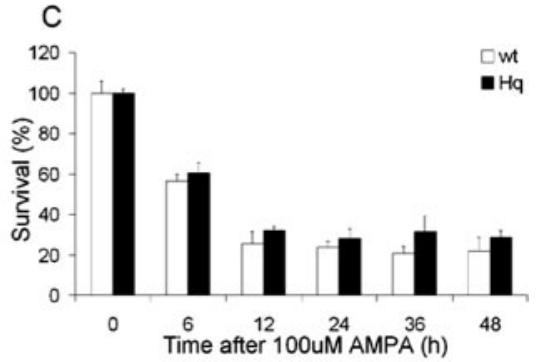

$\mathrm{E}$

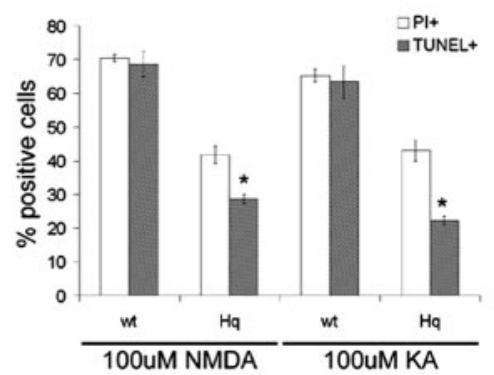

Figure 9. Hq cortical neurons are more resistant to excitotoxicity induced by NMDA and kainate but not AMPA. Cortical neurons (14 DIV) from wild-type (wt) and $\mathrm{Hq}$ littermates were treated with $100 \mu \mathrm{m} \operatorname{NMDA}(A), 100 \mu \mathrm{m}$ kainic acid ( $B)$, and $100 \mu \mathrm{M}$ AMPA ( $C$ ) for $1 \mathrm{~h}$ with the appropriate coagonists, desensitization blockers, and specific receptor blockers (see Materials and Methods) ( $n=$ 3). Survival was determined by nuclear morphology using Hoechst stain. Di, Nuclear translocation of AIF assessed by AIF immunohistochemistry after NMDA, kainate, and AMPA treatment ( $n=3$ ). Dii, Photomicrographs of AIF immunohistochemistry show the lack of nuclear translocation after AMPA treatment. Scale bar, $10 \mu \mathrm{m}$. E, Quantitative analysis of PI-positive (PI+) and TUNEL-positive (TUNEL + ) neurons $36 \mathrm{~h}$ after NMDA and kainate treatment $(n=3) .{ }^{*} p<0.01$ compared with wild-type $(A, B)$ or PI positive $(C)$.

\section{The importance of AIF in excitotoxic neuronal injury}

Excitotoxicity is a major contributor to many neurodegenerative diseases, such as ischemia and acute neurotrauma (Arundine and Tymianski, 2003; Yuan et al., 2003). During stroke or trauma, excitotoxic neuronal damage results from an excessive release and impaired reuptake of the neurotransmitter glutamate from synapses. There are several receptors for glutamate, but the key mediator in terms of excitotoxic cell death is the NMDA receptor (Arundine and Tymianski, 2003), which, in this system, functions in a BAX-independent (Miller et al., 1997; Dargusch et al., 2001) and caspase-independent (Fig. 5) manner. Once activated by excessive levels of glutamate, the NMDA receptors allow excessive calcium ion influx and elevated cytoplasmic calcium ion levels. This influx of calcium ions activates neuronal nitric oxide synthase and unleashes the subsequent overactivation of PARP1 attributable to oxidative DNA damage (Yu et al., 2003; Cregan et al., 2004). Recently, it was demonstrated that PARP1 induces AIF translocation in NMDA-induced cell death. In PARP1-deficient neurons, AIF does not translocate to nucleus, and cell death is abolished after NMDA application (Yu et al., 2002). These studies implicate AIF as a key death effector in glutamate-induced excitotoxicity. Surprisingly, a previous study with $\mathrm{Hq}$ mice revealed that neurons with reduced AIF were found to be more sensitive to high doses of glutamate (Klein et al., 2002). In the present study, we used a transient and lower concentration $(100 \mu \mathrm{M})$ of glutamate treatment and showed that $\mathrm{Hq}$ neurons, similar to the knock-out neurons of its upstream regulator PARP1 (Eliasson et al., 1997), are more resistant to excitotoxicity for up to at least $48 \mathrm{~h}$. Importantly, we also show that, at this concentration, glutamate toxicity is NMDA receptor specific because the toxicity is inhibited completely by MK- 801 .

The discrepancy between our studies and those reported previously by Klein et al. (2002) regarding the role of AIF in glutamate-mediated cell death is attributable to the fact that dis- tinct death signaling pathways are being examined. We are studying glutamate receptor-mediated signaling specifically through the NMDA, kainic acid, and AMPA receptors. These experiments are done according to well established protocols (Sattler et al., 1999; Aarts et al., 2002). In these experiments, cells are exposed to glutamate or agonist transiently for $1 \mathrm{~h}$, which results in activation of receptors that can be specifically inhibited by MK- 801 . Thus, all death signaling induced by glutamate in the present study is through specific glutamate receptors. We show that AIF deficiency in $\mathrm{Hq}$ mice results in protection against this mode of cell death. Our in vitro results are supported by our in vivo experiments using a model of excitotoxicity involving kainic acidinduced seizure. At $4 \mathrm{~d}$ after treatment, $\mathrm{Hq}$ adult mice were more resistant to excitotoxic brain damage relative to their wild-type littermates. $\mathrm{Hq}$ mice sustained similar seizure symptoms as wildtype mice because AIF does not contribute to the electrical excitability of these neurons. All of these results demonstrate that AIF is important in inducing cell death after excitotoxicity and, by reducing its expression, neurons are protected against NMDAand kainic acid receptor-mediated injury. In contrast, studies by Klein et al. (2002) focus on non-excitotoxic cell death involving chronic glutamate exposure at relatively high concentrations. With this type of exposure, multiple pathways, including those involving oxidative stress, are evoked. This type of cell death is non-excitotoxic and cannot be inhibited by MK-801 (data not shown) and is not protected by the $\mathrm{Hq}$ mutation. Consistent with the results of Klein et al. (2002), we obtained similar results showing that $\mathrm{Hq}$ neurons are more sensitive to oxidative stress (data not shown). Thus, exposure to glutamate can evoke multiple death pathways, and the results of our experiments show that AIF reduction is protective to the excitotoxic mode of cell death specifically involving activation of NMDA and kainic acid glutamate receptors. This type of death pathway is directly involved in seizure-, trauma-, and stroke-induced acute brain damage. 

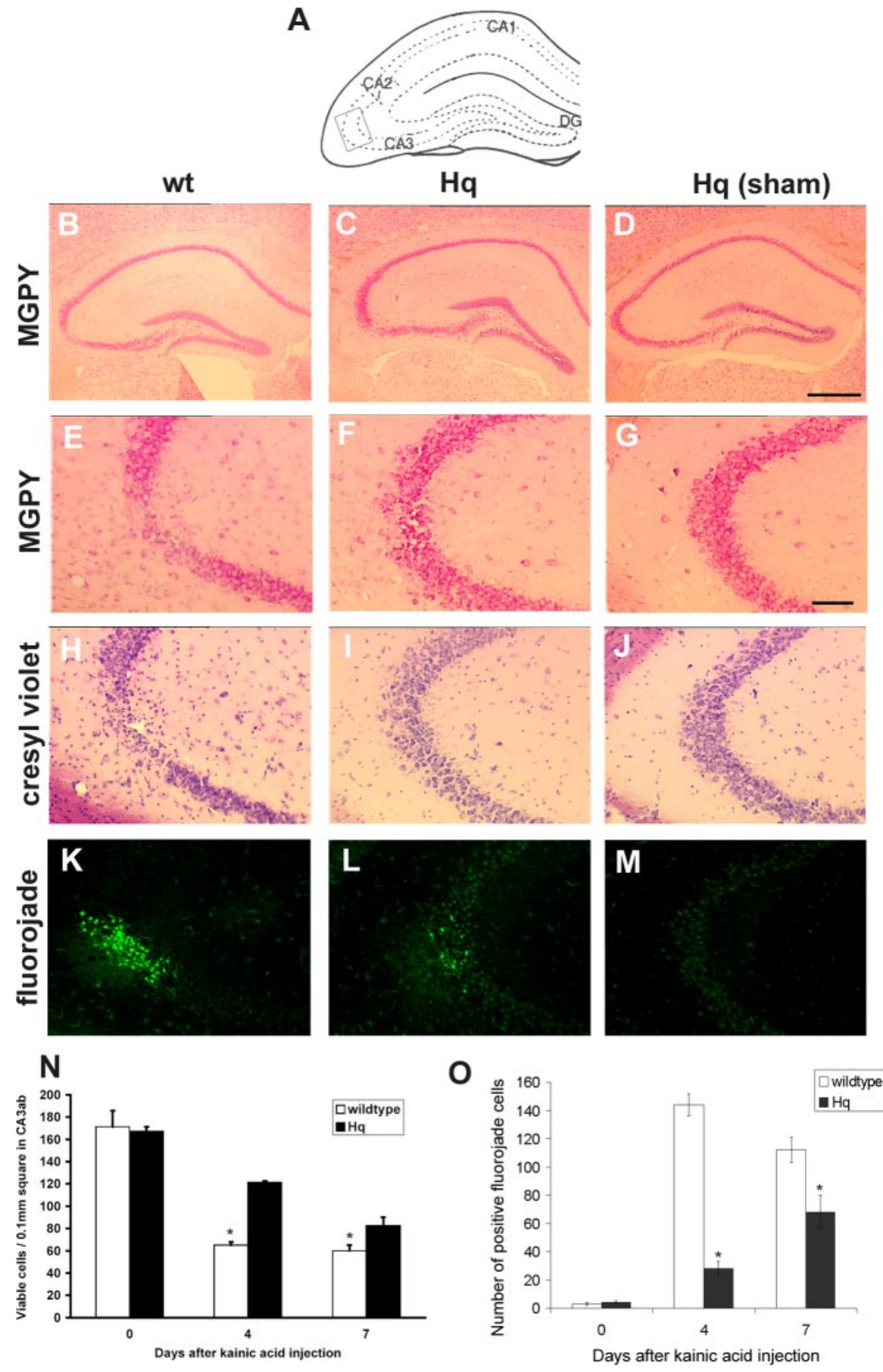

Figure 10. Hq neurons are more resistant to excitotoxicity in vivo induced by kainic acid seizure in adult mice. Animals were injected with kainic acid ( $30 \mathrm{mg} / \mathrm{kg}$ ) and killed 4 or $7 \mathrm{~d}$ afterward. $A$, Diagram of coronal section of hippocampus. The box indicates the CA3ab region. DG, Dentate gyrus. $B-D, M G P Y$ staining was used to assess viability. Scale bar, $500 \mu \mathrm{m}$. E-G, MGPY staining at higher magnification. Scale bar, $100 \mu \mathrm{m}$. $H-J$, Cresyl violet staining. $K-M$, FluoroJade staining was used to assess cell death. Sham is Hq mice. N, Quantification of viable cells per $0.1 \mathrm{~mm}^{2}$ in CA3ab area by MGPY stain $(n=3) .{ }^{*} p<0.01$ compared with wild type. 0 , Quantification of cell death in the CA3ab area by FluoroJade staining $(n=3) .{ }^{*} p<0.05$ compared with wild type.

In summary, the results of our studies demonstrate that the reduction of AIF combined with caspase inhibition provides extended neuroprotection against BAX-mediated apoptosis. Also, neurons with reduced AIF are protected against excitotoxicity specifically through the activation of NMDA receptors and kainic acid receptors. Consistent with our in vitro results, in an in vivo model of excitotoxicity, $\mathrm{Hq}$ adult mice exhibited less hippocampal damage induced by kainic acid treatment. Our results show that AIF is a key determinant in caspase-independent death cascades involving both BAXdependent and BAX-independent death pathways. Because of its activity in multiple death pathways, AIF may serve as a promising therapeutic target for the treatment of acute brain injury and neurodegenerative diseases.

\section{References}

Aarts M, Liu Y, Liu L, Besshoh S, Arundine M, Gurd JW, Wang YT, Salter MW, Tymianski M (2002) Treatment of ischemic brain damage by perturbing NMDA receptor- PSD-95 protein interactions. Science 298:846-850.

Al-Hazzaa AA, Bowen ID (1998) Improved cytochemical methods for demonstrating cell death using LR White as an embedding medium. Histochem J 30:897-902.

Arnoult D, Parone P, Martinou JC, Antonsson B, Estaquier J, Ameisen JC (2002) Mitochondrial release of apoptosis-inducing factor occurs downstream of cytochrome $\mathrm{c}$ release in response to several proapoptotic stimuli. J Cell Biol 159:923-929.

Arnoult D, Gaume B, Karbowski M, Sharpe JC, Cecconi F, Youle RJ (2003) Mitochondrial release of AIF and EndoG requires caspase activation downstream of Bax/Bak-mediated permeabilization. EMBO J 22:4385-4399.

Arundine M, Tymianski M (2003) Molecular mechanisms of calcium-dependent neurodegeneration in excitotoxicity. Cell Calcium 34:325-337.

Bennett SA, Stevenson B, Staines WA, Roberts DC (1995) Periodic acid-Schiff (PAS)-positive deposits in brain following kainic acidinduced seizures: relationships to fos induction, neuronal necrosis, reactive gliosis, and blood-brain barrier breakdown. Acta Neuropathol (Berl) 89:126-138.

Bennett SA, Tenniswood M, Chen JH, Davidson CM, Keyes MT, Fortin T, Pappas BA (1998) Chronic cerebral hypoperfusion elicits neuronal apoptosis and behavioral impairment. NeuroReport 9:161-166.

Cande C, Cecconi F, Dessen P, Kroemer G (2002a) Apoptosis-inducing factor (AIF): key to the conserved caspase-independent pathways of cell death? J Cell Sci 115:4727-4734.

Cande C, Cohen I, Daugas E, Ravagnan L, Larochette N, Zamzami N, Kroemer G (2002b) Apoptosis-inducing factor (AIF): a novel caspase-independent death effector released from mitochondria. Biochimie 84:215-222.

Cregan SP, MacLaurin JG, Craig CG, Robertson GS, Nicholson DW, Park DS, Slack RS (1999) Bax-dependent caspase- 3 activation is a key determinant in p53-induced apoptosis in neurons. J Neurosci 19:7860-7869.

Cregan SP, Fortin A, MacLaurin JG, Callaghan SM, Cecconi F, Yu SW, Dawson TM, Dawson VL, Park DS, Kroemer G, Slack RS (2002) Apoptosis-inducing factor is involved in the regulation of caspaseindependent neuronal cell death. J Cell Biol 158:507-517.

Cregan SP, Dawson VL, Slack RS (2004) Role of AIF in caspase-dependent and caspase-independent cell death. Oncogene 23:2785-2796.

Danial NN, Korsmeyer SJ (2004) Cell death: critical control points. Cell 116:205-219.

Dargusch R, Piasecki D, Tan S, Liu Y, Schubert D (2001) The role of Bax in glutamate-induced nerve cell death. J Neurochem 76:295-301. 
Daugas E, Susin SA, Zamzami N, Ferri KF, Irinopoulou T, Larochette N, Prevost MC, Leber B, Andrews D, Penninger J, Kroemer G (2000) Mitochondrio-nuclear translocation of AIF in apoptosis and necrosis. FASEB J 14:729-739.

Dingledine R, Borges K, Bowie D, Traynelis SF (1999) The glutamate receptor ion channels. Pharmacol Rev 51:7-61.

Eliasson MJ, Sampei K, Mandir AS, Hurn PD, Traystman RJ, Bao J, Pieper A, Wang ZQ, Dawson TM, Snyder SH, Dawson VL (1997) Poly(ADPribose) polymerase gene disruption renders mice resistant to cerebral ischemia. Nat Med 3:1089-1095.

Endres M, Wang ZQ, Namura S, Waeber C, Moskowitz MA (1997) Ischemic brain injury is mediated by the activation of poly(ADPribose)polymerase. J Cereb Blood Flow Metab 17:1143-1151.

Endres M, Namura S, Shimizu-Sasamata M, Waeber Shimizu-Sasamata, Zhang L, Gomez-Isla T, Hyman BT, Moskowitz MA (1998) Attenuation of delayed neuronal death after mild focal ischemia in mice by inhibition of the caspase family. J Cereb Blood Flow Metab 18:238-247.

Ferguson KL, Vanderluit JL, Hebert JM, McIntosh WC, Tibbo E, MacLaurin JG, Park DS, Wallace VA, Vooijs M, McConnell SK, Slack RS (2002) Telencephalon-specific Rb knockouts reveal enhanced neurogenesis, survival and abnormal cortical development. EMBO J 21:3337-3346.

Fortin A, Cregan SP, MacLaurin JG, Kushwaha N, Hickman ES, Thompson CS, Hakim A, Albert PR, Cecconi F, Helin K, Park DS, Slack RS (2001) APAF1 is a key transcriptional target for p53 in the regulation of neuronal cell death. J Cell Biol 155:207-216.

Huettner JE (1990) Glutamate receptor channels in rat DRG neurons: activation by kainate and quisqualate and blockade of desensitization by Con A. Neuron 5:255-266.

Huettner JE, Bean BP (1988) Block of N-methyl-D-aspartate-activated current by the anticonvulsant MK-801: selective binding to open channels. Proc Natl Acad Sci USA 85:1307-1311.

Joza N, Susin SA, Daugas E, Stanford WL, Cho SK, Li CY, Sasaki T, Elia AJ, Cheng HY, Ravagnan L, Ferri KF, Zamzami N, Wakeham A, Hakem R, Yoshida H, Kong YY, Mak TW, Zuniga-Pflucker JC, Kroemer G, Penninger JM (2001) Essential role of the mitochondrial apoptosisinducing factor in programmed cell death. Nature 410:549-554.

Klein JA, Longo-Guess CM, Rossmann MP, Seburn KL, Hurd RE, Frankel WN, Bronson RT, Ackerman SL (2002) The harlequin mouse mutation downregulates apoptosis-inducing factor. Nature 419:367-374.

Komjati K, Mabley JG, Virag L, Southan GJ, Salzman AL, Szabo C (2004) Poly (ADP-ribose)polymerase inhibition protect neurons and the white matter and regulates the translocation of apoptosis-inducing factor in stroke. Int J Mol Med 13:373-382.

Lang-Rollin IC, Rideout HJ, Noticewala M, Stefanis L (2003) Mechanisms of caspase-independent neuronal death: energy depletion and free radical generation. J Neurosci 23:11015-11025.

Lorenzo HK, Susin SA, Penninger J, Kroemer G (1999) Apoptosis inducing factor (AIF): a phylogenetically old, caspase-independent effector of cell death. Cell Death Differ 6:516-524.

Mandir AS, Poitras MF, Berliner AR, Herring WJ, Guastella DB, Feldman A, Poirier GG, Wang ZQ, Dawson TM, Dawson VL (2000) NMDA but not non-NMDA excitotoxicity is mediated by Poly(ADP-ribose) polymerase. J Neurosci 20:8005-8011.

McIntyre DC, Nathanson D, Edson N (1982) A new model of partial status epilepticus based on kindling. Brain Res 250:53-63.

Miller TM, Moulder KL, Knudson CM, Creedon DJ, Deshmukh M, Korsmeyer SJ, Johnson Jr EM (1997) Bax deletion further orders the cell death pathway in cerebellar granule cells and suggests a caspaseindependent pathway to cell death. J Cell Biol 139:205-217.

Moffitt P (1994) A methyl green-pyronin technique for demonstrating cell death in the murine tumour S180. Cell Biol Int 18:677-679.

Moroni F, Meli E, Peruginelli F, Chiarugi A, Cozzi A, Picca R, Romagnoli P, Pellicciari R, Pellegrini-Giampietro DE (2001) Poly(ADP-ribose) poly- merase inhibitors attenuate necrotic but not apoptotic neuronal death in experimental models of cerebral ischemia. Cell Death Differ 8:921-932.

Parrish JZ, Yang C, Shen B, Xue D (2003) CRN-1, a Caenorhabditis elegans FEN-1 homologue, cooperates with CPS-6/EndoG to promote apoptotic DNA degradation. EMBO J 22:3451-3460.

Paternain AV, Morales M, Lerma J (1995) Selective antagonism of AMPA receptors unmasks kainate receptor-mediated responses in hippocampal neurons. Neuron 14:185-189.

Plesnila N, Zhu C, Culmsee C, Groger M, Moskowitz MA, Blomgren K (2004) Nuclear translocation of apoptosis-inducing factor after focal cerebral ischemia. J Cereb Blood Flow Metab 24:458-466.

Sattler R, Xiong Z, Lu WY, Hafner M, MacDonald JF, Tymianski M (1999) Specific coupling of NMDA receptor activation to nitric oxide neurotoxicity by PSD- 95 protein. Science 284:1845-1848.

Schmued LC, Albertson C, Slikker Jr W (1997) Fluoro-Jade: a novel fluorochrome for the sensitive and reliable histochemical localization of neuronal degeneration. Brain Res 751:37-46.

Strain SM, Tasker RA (1991) Hippocampal damage produced by systemic injections of domoic acid in mice. Neuroscience 44:343-352.

Susin SA, Lorenzo HK, Zamzami N, Marzo I, Brenner C, Larochette N, Prevost MC, Alzari PM, Kroemer G (1999a) Mitochondrial release of caspase-2 and -9 during the apoptotic process. J Exp Med 189:381-394.

Susin SA, Lorenzo HK, Zamzami N, Marzo I, Snow BE, Brothers GM, Mangion J, Jacotot E, Costantini P, Loeffler M, Larochette N, Goodlett DR, Aebersold R, Siderovski DP, Penninger JM, Kroemer G (1999b) Molecular characterization of mitochondrial apoptosis-inducing factor. Nature 397:441-446.

Susin SA, Daugas E, Ravagnan L, Samejima K, Zamzami N, Loeffler M, Costantini P, Ferri KF, Irinopoulou T, Prevost MC, Brothers G, Mak TW, Penninger J, Earnshaw WC, Kroemer G (2000) Two distinct pathways leading to nuclear apoptosis. J Exp Med 192:571-580.

Wang H, Shimoji M, Yu SW, Dawson TM, Dawson VL (2003) Apoptosis inducing factor and PARP-mediated injury in the MPTP mouse model of Parkinson's disease. Ann NY Acad Sci 991:132-139.

Wang H, Yu SW, Koh DW, Lew J, Coombs C, Bowers W, Federoff HJ, Poirier GG, Dawson TM, Dawson VL (2004) Apoptosis-inducing factor substitutes for caspase executioners in NMDA-triggered excitotoxic neuronal death. J Neurosci 24:10963-10973.

Wang X, Yang C, Chai J, Shi Y, Xue D (2002) Mechanisms of AIF-mediated apoptotic DNA degradation in Caenorhabditis elegans. Science 298:1587-1592.

Wong LA, Mayer ML (1993) Differential modulation by cyclothiazide and concanavalin A of desensitization at native alpha-amino-3-hydroxy-5methyl-4-isoxazolepropionic acid- and kainate-preferring glutamate receptors. Mol Pharmacol 44:504-510.

Ying W, Sevigny MB, Chen Y, Swanson RA (2001) Poly(ADP-ribose) glycohydrolase mediates oxidative and excitotoxic neuronal death. Proc Natl Acad Sci USA 98:12227-12232.

Yu SW, Wang H, Poitras MF, Coombs C, Bowers WJ, Federoff HJ, Poirier GG, Dawson TM, Dawson VL (2002) Mediation of poly(ADP-ribose) polymerase-1-dependent cell death by apoptosis-inducing factor. Science 297:259-263.

Yu SW, Wang H, Dawson TM, Dawson VL (2003) Poly(ADP-ribose) polymerase-1 and apoptosis inducing factor in neurotoxicity. Neurobiol Dis 14:303-317.

Yuan J, Lipinski M, Degterev A (2003) Diversity in the mechanisms of neuronal cell death. Neuron 40:401-413.

Zhang J, Dawson VL, Dawson TM, Snyder SH (1994) Nitric oxide activation of poly(ADP-ribose) synthetase in neurotoxicity. Science 263:687-689.

Zhu C, Qiu L, Wang X, Hallin U, Cande C, Kroemer G, Hagberg H, Blomgren K (2003) Involvement of apoptosis-inducing factor in neuronal death after hypoxia-ischemia in the neonatal rat brain. J Neurochem 86:306317. 